\title{
In vivo kinetics of $\beta$-glucosidase towards glucovanillin and related phenolic glucosides in heat-treated vanilla pod (Vanilla planifolia, Orchidaceae)
}

Jean-Marc BRILLOUET ${ }^{1,2 *}$, Éric Odoux ${ }^{1}$

${ }^{1}$ CIRAD, Persyst, UMR Qualisud, TA B-95 / 16, F-34398 Montpellier Cedex 5, France

brillouet@cirad.fr

2 INRA, UMR 1083,

"Sciences pour l'CEnologie ", Univ. Montpellier I, F-34000 Montpellier Cedex, France
* Correspondence and reprints

Received 28 September 2009 Accepted 3 November 2009

Fruits, 2010, vol. 65, p. 85-95 (C) 2010 Cirad/EDP Sciences All rights reserved DOI: $10.1051 /$ fruits/20010004 www.fruits-journal.org

RESUMEN ESPAÑOL, p. 95
In vivo kinetics of $\beta$-glucosidase towards glucovanillin and related phenolic glucosides in heat-treated vanilla pod (Vanilla planifolia, Orchidaceae).

Abstract - Introduction. The traditional curing of vanilla pods includes "killing" and sweating steps when pods are exposed to heat $\left(35-65^{\circ} \mathrm{C}\right)$ for various lengths of time. Although it is known that liberation of vanillin and other phenolics from their non-aromatic glucosides is due to the action of an endogenous $\beta$-glucosidase, its in vivo kinetics remained unknown. Materials and methods. Mature green vanilla pods were pretreated for $2 \mathrm{~h}$ at $50{ }^{\circ} \mathrm{C}, 55^{\circ} \mathrm{C}$ and $60^{\circ} \mathrm{C}$, then stored for 118 days at $27^{\circ} \mathrm{C}$. Phenolic glucosides and their aglycons were extracted at regular intervals during the storage period and analyzed by HPLC. Results and discussion. All phenolic $\beta$-glucosides were slowly hydrolyzed during the storage period with production of vanillin, $p$-hydroxybenzaldehyde, vanillic acid, and other unknown aglycons. Most of the $\beta$-glucosidase was heat-denatured by the pretreatment, and analysis of its kinetic parameters showed that it adopts, in vivo, an allosteric mode of functioning with a lower affinity for glucovanillin than in vitro, where it behaves as a Michaelian enzyme. Conclusion. Extensive research is needed to confirm the allosteric mechanism of the vanilla $\beta$-glucosidase in vivo.

France / Vanilla planifolia / vanilla / processing / heat / glucovanillin / $\beta$-glucosidase / affinity constant / allostery

Cinétique de fonctionnement in vivo d'une $\beta$-glucosidase vers la libération de la glucovanillin et de glucosides phénoliques connexes dans la gousse de vanille soumise à un traitement thermique (Vanilla planifolia, Orchidaceae).

Résumé - Introduction. Le procédé traditionnel de préparation des gousses de vanille comprend une étape d'échaudage et une d'étuvage pendant lesquelles les gousses sont soumises à la chaleur $\left(35-65^{\circ} \mathrm{C}\right)$ pendant des durées variables. Bien que l'on sache que la libération de la vanilline et autres composés phénoliques à partir de leurs glucosides non aromatiques est due à l'action d'une $\beta$-glucosidase endogène, ses paramètres cinétiques de fonctionnement in vivo ne sont pas connus. Matériel et méthodes. Des gousses vertes matures ont tout d'abord été traitées pendant $2 \mathrm{~h}$ à, respectivement, $50^{\circ} \mathrm{C}, 55^{\circ} \mathrm{C}$ et $60^{\circ} \mathrm{C}$, puis stockées pendant 118 jours à $27^{\circ} \mathrm{C}$. Les glucosides de phénols et leurs aglycones ont été extraits à intervalles réguliers pendant la période de stockage et analysés par HPLC. Résultats et discussion. Tous les glucosides de phénols ont été lentement hydrolysés pendant la période de stockage avec libération de vanilline, $p$-hydroxybenzaldéhyde, acide vanillique et autres aglycones inconnus. L'essentiel de l'activité $\beta$-glucosidase a été dénaturé par la chaleur pendant le traitement préliminaire et l'analyse de ses paramètres cinétiques a montré que l'enzyme adopte, in vivo, un mode de fonctionnement allostérique avec une affinité pour la glucovanilline plus faible qu'in vitro où elle se comporte comme une enzyme michaélienne. Conclusion. La confirmation du mécanisme allostérique de la $\beta$-glucosidase in vivo de vanille requiert une recherche approfondie.

France / Vanilla planifolia / vanille / traitement / chaleur / glucovanilline / $\beta$-glucosidase / constante d'affinité / allostérie 


\section{Introduction}

The vanilla pod, a berry which turns into a capsule upon drying [1-3], is a generator of a highly prized aroma; it owns its full enzyme-substrate equipment, made up of a $\beta$-glucosidase $[4,5]$ and phenolic $\beta$-D-glucosides [6] which, under certain conditions, are brought together with subsequent hydrolytic release of flavoring aglycons, mostly vanillin [2, 7-12]. Anatomical distributions of the $\beta$-glucosidase and its substrates have recently been extensively described [3, 4, 13, 14].

Vanilla pods are harvested at the green mature stage, lacking at that time the characteristic vanilla flavor; further processing of the pods (the traditional "curing") includes four steps: "killing" (or scalding), sweating, drying and conditioning [8, 9, 15]. The first "killing" phase, when pods are dipped in hot water (typically $50-60^{\circ} \mathrm{C}, 3 \mathrm{~min}$ ) [15], aims at arresting the vegetative development of the pod, i.e., to prevent the dehiscence detrimental to the final quality [8]; during this later and subsequent phases, multiple biological, chemical and physical events happen (hydrolysis, oxidation, water loss, migration, crystallization and sublimation of substances, microbial development, etc.) which in the end result in semi-dry vanilla

Figure 1.

Green mature vanilla pods.

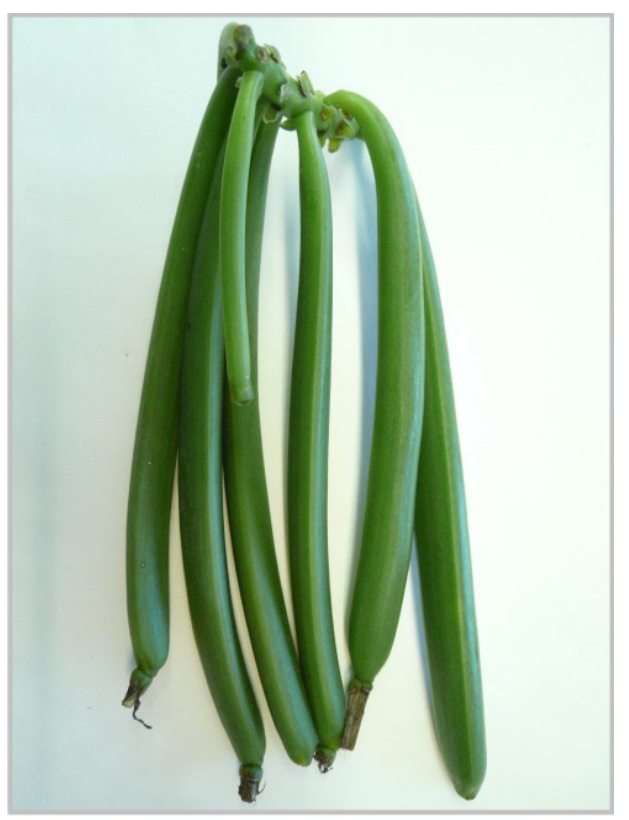

pods of various quality attributes. Numerous studies have been devoted to elucidation of the various mechanisms involved [2, 7, 912,16-18], the first crucial event being the hydrolysis of phenolic $\beta$-glucosides by a $\beta$-glucosidase: Odoux et al. [5] purified and characterized a vanilla $\beta$-glucosidase, while Dignum et al. [10] studied the in vitro kinetics of a crude $\beta$-glucosidase on several vanilla $\beta$-glucosides. However, the in vivo mode of action of this $\beta$-glucosidase activity is still not fully understood: it has been suggested, for instance, that the emergence of certain aroma compounds in heat-treated pods (e.g., $p$-cresol) would not result from an enzymatic breakdown of their glucosides [11], although $p$-cresol $\beta$-glucoside has been described by Kanisawa [6], and its aglycon is a constituent of the vanilla flavor; also, the same authors suggested, since the $\beta$-glucosidase activity, non-specifically measured on $p$-nitrophenyl $\beta$-D-glucopyranoside, is no longer measurable after "killing" and since nevertheless $\beta$-glucosides slowly disappear from the pods, the existence of another $\beta$-glucosidase "specific" to glucovanillin which would somewhat resist the heat treatment. The existence of two $\beta$-glucosidases in the pod, one of them being "specific" to glucovanillin, had been previously mentioned by Kanisawa [19] but its reality had never been formally confirmed.

Márquez and Waliszewski studied the in vitro kinetics of thermal inactivation of a vanilla $\beta$-glucosidase crude extract [12]. However, and to our knowledge, no results were ever reported on the in vivo kinetics of this enzyme. Since the behavior of an enzyme might differ noticeably in a test tube assay (in vitro) and in its natural environment (in vivo), the aim of our work was thus to describe in detail kinetics of the $\beta$-glucosidase on vanilla pod $\beta$-glucosides in heat-treated vanilla pods (in vivo).

\section{Materials and methods}

\subsection{Materials}

Sound mature green vanilla pods were harvested 8 months after pollination (Réunion Island, France) (figure 1). 
Vanillin, vanillic acid, p-hydroxybenzaldehyde, $\alpha$-D-acetobromoglucose and $p$-nitrophenyl $\beta$-D-glucopyranoside ( $p \mathrm{NPG}$ ) were from Fluka (Buchs, Switzerland). All other chemicals and solvents were of the highest available quality. Synthesis of glucosides was achieved according to Dignum et al. [10].

\subsection{Heat treatment of vanilla pods}

For heat treatment, the middle region of vanilla pods was transversally sliced into twelve adjacent sections (plus one located in the middle of the pod which will be used for $\beta$-glucosidase measurements) $(\sim 3 \mathrm{~mm}$ thickness) and slices were sealed in a polyethylene bag and placed for $2 \mathrm{~h}$ in a temperature-controlled water bath $\left(50^{\circ} \mathrm{C}\right.$, $55^{\circ} \mathrm{C}$ and $60{ }^{\circ} \mathrm{C}$, respectively). Slices were then removed and kept at $27^{\circ} \mathrm{C}$ for 118 days, one slice being withdrawn and frozen every $\sim 10$ days. They were then analyzed for their $\beta$-glucosidase activity and phenolic contents.

\subsection{Extraction and determination of glucovanillin and related phenolics}

Extraction and determination of glucovanillin and related phenolics were performed according to Odoux and Brillouet [3]: briefly, sections ( $150 \mathrm{mg}$ each) were extracted by [methanol:water] $(50: 50, \mathrm{v} / \mathrm{v})$; after centrifugation, the supernatant was then submitted to quantitative analysis by HPLC separation of phenolics and their glycoconjugates on a $(250 \mathrm{~mm} \times 4.6 \mathrm{~mm})$ Modulocart QSLichrospher 5-m ODS2 column operated at $0.5 \mathrm{~mL} \cdot \mathrm{min}^{-1}$ and $30^{\circ} \mathrm{C}$. The mobile phase consisted of [water:formic acid] (98:2, v/v) (eluant A) and [water:acetonitrile:formic acid] $(18: 78: 2, \mathrm{v} / \mathrm{v} / \mathrm{v})$ (eluant B). The elution program was as follows: 8 13\% eluant B ( $0-10 \mathrm{~min}) ; 13-20 \%$ eluant B (10-30 $\mathrm{min}) ; 20-8 \%$ eluant B (30-35 $\mathrm{min})$. The column effluent was monitored at $280 \mathrm{~nm}$. Triplicate samples were injected at a level of $10 \mu \mathrm{L}$. External standardization was achieved with pure glucovanillin (ChromaDex, Irvine, CA), synthetic glucosides and commercial aglycons. Data were expressed either as $\mathrm{mM}$ in the water phase of the pods, i.e., water content $85 \%$ (kinetic study), or $\%$ of fresh weight.

\subsection{Extraction and measurement of the $\beta$-glucosidase activity}

After heat treatment (i.e., at time zero of the storage period), withdrawn pod sections $(\sim 150 \mathrm{mg}$, central region) were dilacerated at ambient temperature in $50 \mathrm{~mL}$ of $0.1 \mathrm{M}$ phosphate buffer ( $\mathrm{pH}$ 7.0). After centrifugation $\left(14000 \mathrm{~g}, 5 \mathrm{~min}, 20^{\circ} \mathrm{C}\right.$ ), the filtrate was diluted $10 \times$ with the same buffer.

Activity was measured as described in Odoux et al. [5]: briefly, an aliquot of enzyme extract was added to $200 \mu \mathrm{L}$ of $4 \mathrm{mM} p$-nitrophenyl $\beta$-D-glucopyranoside in the above phosphate buffer and the total volume was made up to $400 \mu \mathrm{L}$ with phosphate buffer. After $20 \mathrm{~min}$ of incubation at $40{ }^{\circ} \mathrm{C}, 1 \mathrm{~mL}$ of $0.5 \mathrm{M} \mathrm{NaOH}$ was added and the optical density was read at $\lambda=400 \mathrm{~nm}$. Activity was also measured on glucovanillin [5]. It was expressed as nanokatals, i.e., 1 nKat being the amount of enzyme hydrolyzing 1 nanomole of substrate per sec.

\subsection{Purification of the vanilla $\beta$-glucosidase}

Purification of the vanilla $\beta$-glucosidase was performed from $1 \mathrm{~kg}$ of mature green vanilla pods ( $\sim 8$ months after pollination) according to Odoux et al. [5].

\section{Results}

\subsection{Kinetics of the purified vanilla $\beta$-glucosidase}

We formerly published the purification and characterization of the vanilla $\beta$-glucosidase [5] and gave its $K_{\mathrm{m}}$ on $p$-nitrophenyl $\beta$-glucoside and glucovanillin. Having purified higher quantities of this enzyme for a future preparation of antibodies, we again measured these constants with twelve concentrations of each substrate: an excellent linearity of the reciprocal $1 / \mathrm{v}=\mathrm{f}(1 / \mathrm{s})$ was obtained (figure 2). Corrected values are: $K_{\mathrm{m}}=4.3 \pm$ $0.1 \mathrm{mM}$ on $p$-nitrophenyl $\beta$-glucoside, and $K_{\mathrm{m}}=5.0 \pm 0.2 \mathrm{mM}$ on glucovanillin. 
Figure 2.

Reciprocal representation [1/ $v=f(1 / s)]$ for $\beta$-glucosidase with $p$-nitrophenyl $\beta$-D-glucopyranoside ( $p N P G$ ) and glucovanillin as substrates.

\section{Figure 3.}

Time curves of glucovanillin hydrolysis in heat-treated vanilla sections.
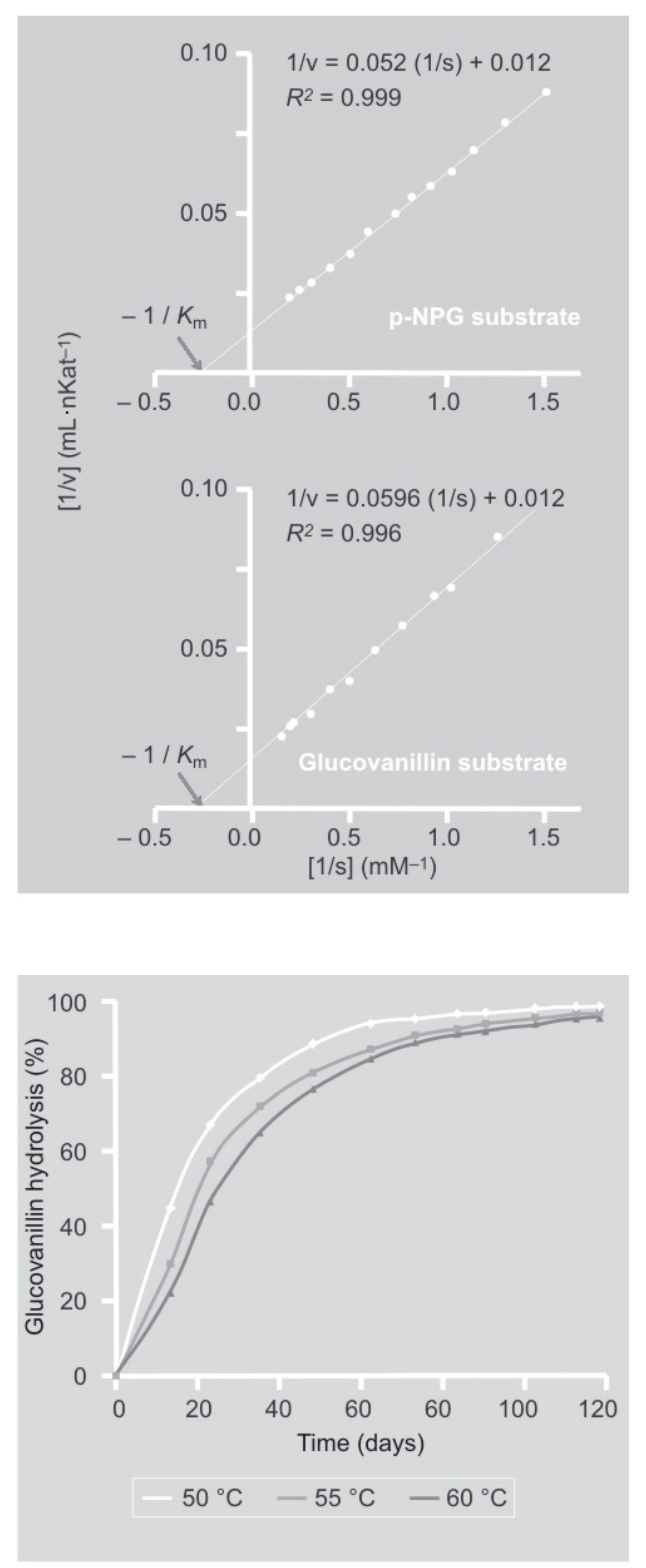

\subsection{Fate of phenolics and the $\beta$-glucosidase after heat treatment}

It must first be noted that the slice water content did not change during the heat pretreatment and subsequent storage, since they were stored in sealed gas- and waterproof polyethylene bags; this was checked on separate experiments. No mold development or microbial alteration were detected either. The starting green mature pods contained $(130 \pm 7) \mathrm{mM}$ glucovanillin.
As previously mentioned [9, 20], no $\beta$-glucosidase activity was measurable after the preliminary heat treatment, even on undiluted extracts (data not shown).

We thus measured the disappearance of glucovanillin, its substrate, during the storage period (figure 3). Although hydrolysis started during the preliminary heat treatment [20], the beginning of hydrolysis was taken to be at the end of this treatment, i.e., at time zero of storage; indeed, for calculation of the affinity constant for glucovanillin, one must have identical conditions of temperature in time (i.e., $27^{\circ} \mathrm{C}$ ). As expected [8], its concentration decreased slowly over time, reaching a very low level after 118 days, and the rate of hydrolysis $\left(v_{\text {hyd }}\right)$ was clearly related during the first 13 days of storage to the temperature of the preliminary 2 -h heat treatment, i.e., $v_{\text {byd }}\left(50^{\circ}{ }^{\circ}\right)>$ $v_{\text {hyd }}\left(55^{\circ} \mathrm{C}\right)>v_{\text {byd }}\left(60^{\circ} \mathrm{C}\right)$; during this period, since the glucovanillin concentration was high $(\sim 50-100 \mathrm{mM})$, the reaction rate was zero-order with time, i.e., maximum velocity $V_{\max }$. Although the terminal percentages of hydrolysis were similar ( 96-98\%), the final glucovanillin concentration was also related to the temperature pretreatment, i.e., the higher this temperature, the higher the residual glucovanillin ( $\sim 4 \%$ of initial amount), and reciprocally $(\sim 2 \%)$; this suggests that a residual non-measurable amount of $\beta$-glucosidase activity was at work.

Starting from the hydrolysis curve obtained for $55^{\circ} \mathrm{C}$ heat treatment, the first derivative was obtained, giving the velocity of reaction $[v]$ at different moments where the concentration of glucovanillin [glcva] was known (figure 4). The reaction velocity was then expressed as variation in glucovanillin: 1 unit of millimolarity $(\mathrm{mM})$ in the tissues per day, millimolarity of glucovanillin calculated as the amount of millimoles present in a given volume of the water phase present in the pods (water content $\sim 85 \%$ ). One can see a typical sigmoid curve where, in the terminal phase of storage when the residual glucovanillin was very low, the reaction rate did not vary linearly with substrate concentration as in the Michaelian model; when glucovanillin was high (initial phase of the storage), the reaction velocity was constant (zero-order). If one admits that the amount of residual enzyme did not 
change during the storage period at $27^{\circ} \mathrm{C}$, one has to consider figure 4 as a typical representation of an allosteric mode of action [21] of the vanilla $\beta$-glucosidase, a tetramer [5]; this is also evidenced in the Hanes-Woolf plot and $K_{0.5}$ was taken from a linear interpolation between $28 \mathrm{mM}$ and $100 \mathrm{mM}$ [glcva]: it was $21.8 \mathrm{mM}$. Thus, the affinity of the $\beta$-glucosidase for glucovanillin was decreased in its natural decompartmented medium [11].Then, we built the following Hill plot (figure 4): $v=V_{\mathrm{m}}$. [glcva] $]^{\mathrm{n}} /\left(K_{0.5}{ }^{\mathrm{n}}+\right.$ [glcva $^{\mathrm{n}}$ ), with various $\mathrm{n}$ values. Finally, $\mathrm{n}=2.9$ provided the best fit to the experimental curve.

We measured $K_{\mathrm{m}}$ of the purified enzyme on glucovanillin in conditions mimicking the decompartmented vanilla pod tissue, i.e., $100 \mathrm{mM}$ acetate buffer (pH 5.2) containing $150 \mathrm{mM}$ glucose (i.e., pod sugar content 2.7\%) [3]: in these conditions, its value remained the same as at $\mathrm{pH} 7.0$ in a sugarfree medium, i.e., $5.0 \mathrm{mM}$ [this work], and no allosteric behavior was visible in these dilute conditions.

We obtained two typical HPLC chromatograms of the extraction media from slices at 0 and 118 days of storage (figure 5), UV spectra of the detected peaks (figure 6 ), and their kinetics of appearance-disappearance (figure 7); compounds decreasing with time will be referred to as " $\beta$-glucosides" due to the action of the $\beta$-glucosidase, while those increasing will be named "aglycons" resulting from hydrolysis. Compared with other plant extracts, one must first say that the chromatograms were rather poor in number of peaks observed: indeed, no derivatives of flavonol glucosides or flavan-3-ols were detected. At the beginning of the storage, one can see essentially eight peaks (figure 5): an unknown $\beta$-glucoside $\left(\mathrm{n}^{\circ} 1\right.$, $\lambda_{\max }=275 \mathrm{~nm}$ ), vanillic acid $\beta$-glucoside $\left(\mathrm{n}^{\circ} 2, \lambda_{\max }=254 \mathrm{~nm}, 291 \mathrm{~nm}\right), p$-OHbenzaldehyde $\beta$-glucoside $\left(\mathrm{n}^{\circ} 3, \lambda_{\max }=268 \mathrm{~nm}\right)$, glucovanillin $\left(\mathrm{n}^{\circ} 5, \lambda_{\max }=273 \mathrm{~nm}, 307 \mathrm{~nm}\right)$, $p$-OHbenzaldehyde $\left(\mathrm{n}^{\circ} 11, \lambda_{\max }=284 \mathrm{~nm}\right)$, an unknown $\beta$-glucoside $\left(\mathrm{n}^{\circ} 12, \lambda_{\max }=\right.$ $271 \mathrm{~nm}, 308 \mathrm{~nm})$, vanillin $\left(\mathrm{n}^{\circ} 13, \lambda_{\max }=\right.$ $280 \mathrm{~nm}, 309 \mathrm{~nm})$, and an unknown ( $\mathrm{n}^{\circ} 14$, $\lambda_{\text {max }}=276 \mathrm{~nm}, 303 \mathrm{~nm}$ ). Indeed, after the heat treatment when hydrolysis began, some aglycons had already been released

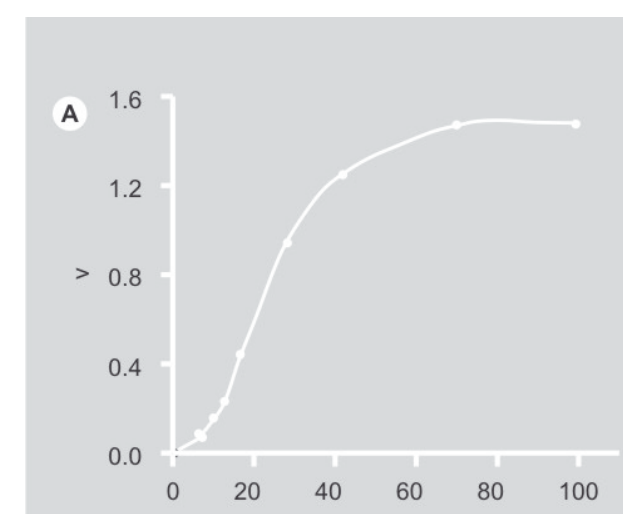

\section{Figure 4.}

Direct (A) and Hanes-Woolf (B) plots of reaction rate with glucovanillin concentration (heat pretreatment at $55^{\circ} \mathrm{C}$ ). In (C) they are compared in experimental and Hill plots.
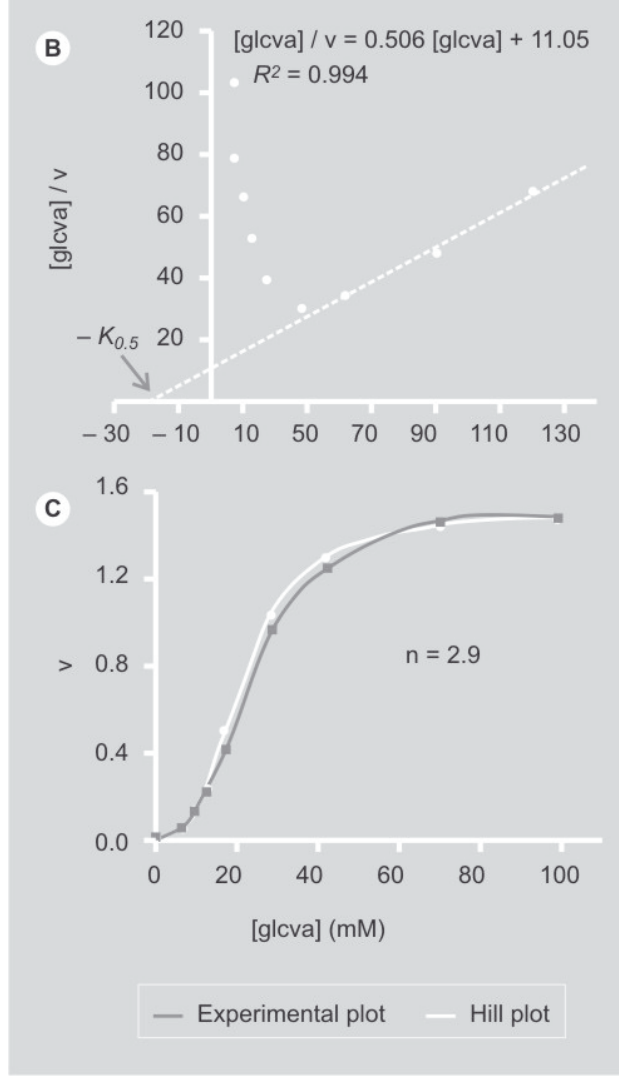

(peaks $\left.n^{\circ} 11,13\right)$; moreover, in native pods, minor quantities of $p$-OHbenzaldehyde and vanillin are always present aside from the glucosides [8]. At time 118 days, fourteen peaks were observed (figure 5); the eight above, plus four unknown aglycons $\left(\mathrm{n}^{\circ} 4\right.$, $\lambda_{\text {max }}=271 \mathrm{~nm}, 307 \mathrm{~nm} ; \mathrm{n}^{\circ} 6, \lambda_{\max }=271 \mathrm{~nm}$, $307 \mathrm{~nm} ; \mathrm{n}^{\circ} 7, \lambda_{\max }=271 \mathrm{~nm}, 306 \mathrm{~nm} ; \mathrm{n}^{\circ} 8$, $\left.\lambda_{\text {max }}=279 \mathrm{~nm}, 309 \mathrm{~nm}\right)$, vanillic acid $\left(\mathrm{n}^{\circ}\right.$ ), $\lambda_{\max }=260 \mathrm{~nm}, 292 \mathrm{~nm}$ ), and a trace of a hydroxycinnamic acid derivative ( $n^{\circ} 10$, 


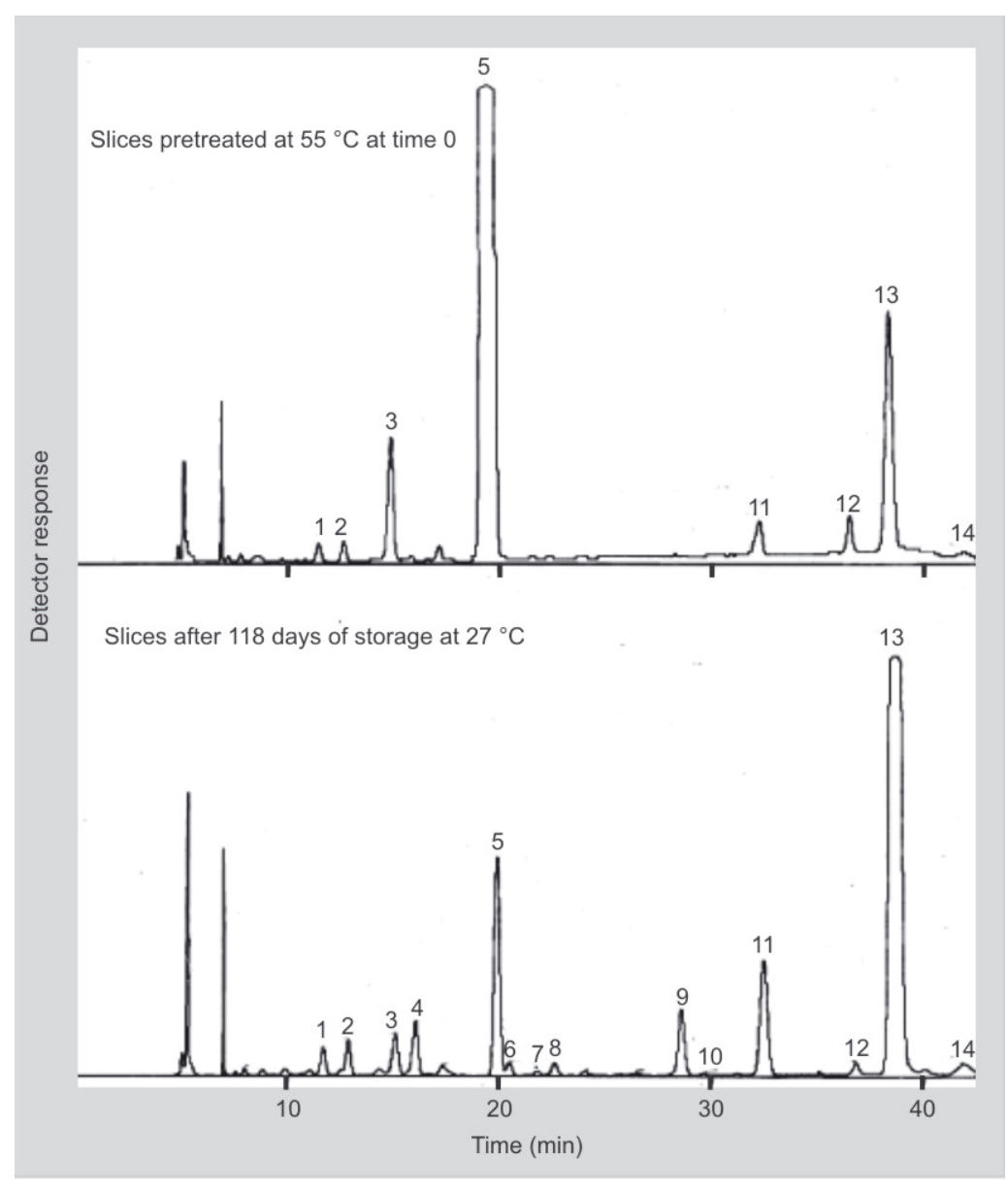

Figure 5.

HPLC chromatograms of the extraction media from different vanilla pod slices pretreated at $55^{\circ} \mathrm{C}$ at times 0 and 118 days of storage at $27^{\circ} \mathrm{C}$. Identities of peaks as follows:

1 unknown glucoside,

2: vanillic acid glucoside,

3: $p$-OHbenzaldehyde

glucoside, 4: unknown

aglycon, 5: glucovanillin,

6: unknown aglycon,

7: unknown aglycon,

8: unknown aglycon, 9: vanillic acid, 10: a hydroxycinnamic acid derivative,

11: $p$-OHbenzaldehyde,

12: unknown glucoside,

13: vanillin, 14: unknown (enlargements of

chromatograms not comparable). $\left.\lambda_{\max }=298 \mathrm{~nm} \mathrm{sh}, 329 \mathrm{~nm}\right)$. One must say that, apart from peaks $n^{\circ} 4,9,11$ and 13, other constituents were present at very low levels; however, they might be important for their contribution in the final vanilla flavor [22].

Apart from vanillic acid $\beta$-glucoside, glucovanillin and their aglycons, a glucoside $\left(n^{\circ} 12\right)$, and four aglycons $\left(n^{\circ} 4,6,7,8\right)$ exhibited typical spectra similar to glucovanillin. According to its late elution time, peak $n^{\circ} 12$ must bear an aglycon of low polarity and could be, according to its late elution time, glucoside A or B [6, 10].

If one examines the curves of appearance-disappearance (figure 7), one can see that glucovanillin was almost fully hydrolyzed after 118 days at $27{ }^{\circ} \mathrm{C}$ (figure 3). Its aglycon, vanillin, reached a plateau corresponding to about one-third of the vanillin liberated from glucovanillin; the same observation is made for $p$-OHbenzaldehyde $\beta$-glucoside and its aglycon. Another unknown aglycon (peak $n^{\circ} 4$ ) behaves similarly; however, its glucoside was not seen in the chromatograms (possible undetected coelution with another peak) and we were thus not able to calculate its hydrolysis percent. Two unknown aglycons $\left(\mathrm{n}^{\circ} 6,7\right)$ behave specifically: they were produced up to a maximum at 23-35 days of storage, then decreased strongly until the end; due to their very low concentrations, their glucosides were not detected.

Other curves of hydrolysis clearly show that, e.g., vanillic acid $\beta$-glucoside $\left(n^{\circ} 2\right)$ was hydrolyzed more slowly with a linear mode ( $50 \%$ in 118 days), due to a much lower starting concentration compared with glucovanillin; its aglycon, vanillic acid $\left(n^{\circ} 9\right)$, was released linearly and did not reach a plateau, like the unknown aglycon $\mathrm{n}^{\circ} 8$. The unknown glucoside $\left(\mathrm{n}^{\circ} 1\right)$ behaves the same ( $\sim 50 \%$ hydrolysis in 118 days), and its aglycon was not observed in the chromatograms (possibly hidden in the vanillin peak [10]).

\section{Discussion}

After having enumerated the numerous possible alterations occurring during and after heat treatment of a vanilla pod, we will discuss our data with regards to them and the literature.

Heat treatment of the pods generates multiple events, most of them being only hypothetical and unsupported (except those with references):

- decompartmentation in the symplasm with disruption of the tonoplast [11], the final fate of the cytoplasmic membrane remaining unknown,

- slow or fast mixing of the vacuolar content with the cytoplasm up to an equilibrium; $\mathrm{pH}$ of the cytoplasm (7.2-7.4) [23] driven to $\mathrm{pH} 5.2-5.4$ by the vacuolar medium, resulting in a symplasm at $\mathrm{pH} 5.2-5.4$,

- modification of the concentrations of solutes (electrolytes, neutral substances, proteins) reaching an equilibrium, change in 
their coefficients of diffusion, and alteration of osmotic equilibria and viscosities,

- unknown alterations in the apoplasm $[\mathrm{pH}$, solubility of cell wall polysaccharides (pectic substances, cross-linking via oxidation (?), permeability of the walls), cell wallbound proteins (extensin, peroxydase), loosening of the cell walls since heat-treated pods are no longer rigid],

- heat denaturation of proteins: extensive in the case of the $\beta$-glucosidase $[9,11,16,19$, 21], limited for the peroxidase activity [9, 21], unknown for other proteins; precipitation of unknown proteins at their isoelectric $\mathrm{pH}_{\mathrm{i}}$ due to alteration of $\mathrm{pH}$ of the cytoplasm,

- hydrolysis of the $\beta$-glucosides [7-9], being initially stored in the vacuole and put in the presence of the cytoplasmic $\beta$-glucosidase by decompartmentation,

- other unknowns.- oxidation of unknown nature (browning, blackening, protein "fining" by tannins?)

Examination of the time curves of hydrolysis of phenolic $\beta$-glucosides revealed that all of them were slowly hydrolyzed (figures 3, 7): actually, this is one of the aims of the curing process in which the maximum production of vanillin is desirable $[2,7-9,15,22]$ The final extent of glucovanillin hydrolysis is clearly related to the temperature used for the heat treatment: the higher the temperature, the lower the percent of hydrolysis, i.e., the lower the amount of residual $\beta$-glucosidase. We have here a classic phenomenon of heat denaturation of an enzyme, which was well described in vitro for a crude vanilla $\beta$-glucosidase by Márquez and Waliszewski [12]. The enzymatic nature of the hydrolytic agent is also visible during the first fortnight of storage when reaction velocities (figure 3) are zero-order with time, thus with substrate concentration (high during this period), i.e., the enzyme works at its maximum rate $V_{\max }$; they are also proportional to the inverse of temperature treatment, i.e., to the amount of available active enzyme $[v=k(e)]$. Thus, one may state first that, considering the enzymatic hydrolysis of glucovanillin alone, i.e., independently of other enzymatic and/or chemical reactions which may occur, the efficiency of the curing process in terms of maximum attainable amount of vanillin is, independently of the

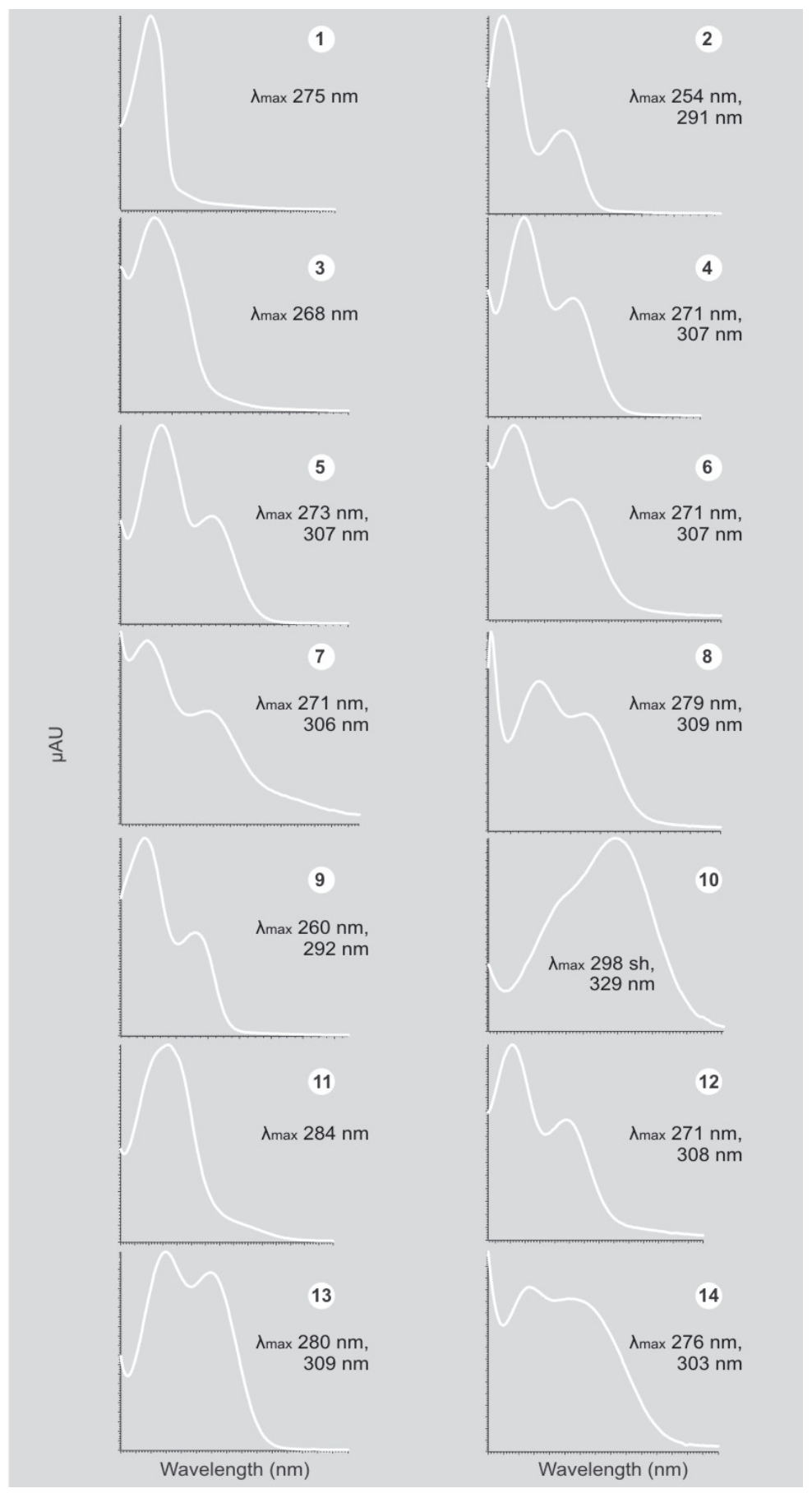

Figure 6.

UV spectra of the compounds detected in the HPLC chromatograms of the extraction media from vanilla pod slices treated at $55^{\circ} \mathrm{C}$. Identities of peaks as follows:

1: unknown glucoside, 2: vanillic acid glucoside, 3: $p$-OHbenzaldehyde glucoside, 4: unknown aglycon, 5: glucovanillin, 6: unknown aglycon, 7: unknown aglycon, 8: unknown aglycon, 9: vanillic acid, 10: a hydroxycinnamic acid derivative, 11: p-OHbenzaldehyde, 12: unknown glucoside, 13: vanillin, 14: unknown. 
J.-M. Brillouet, É. Odoux

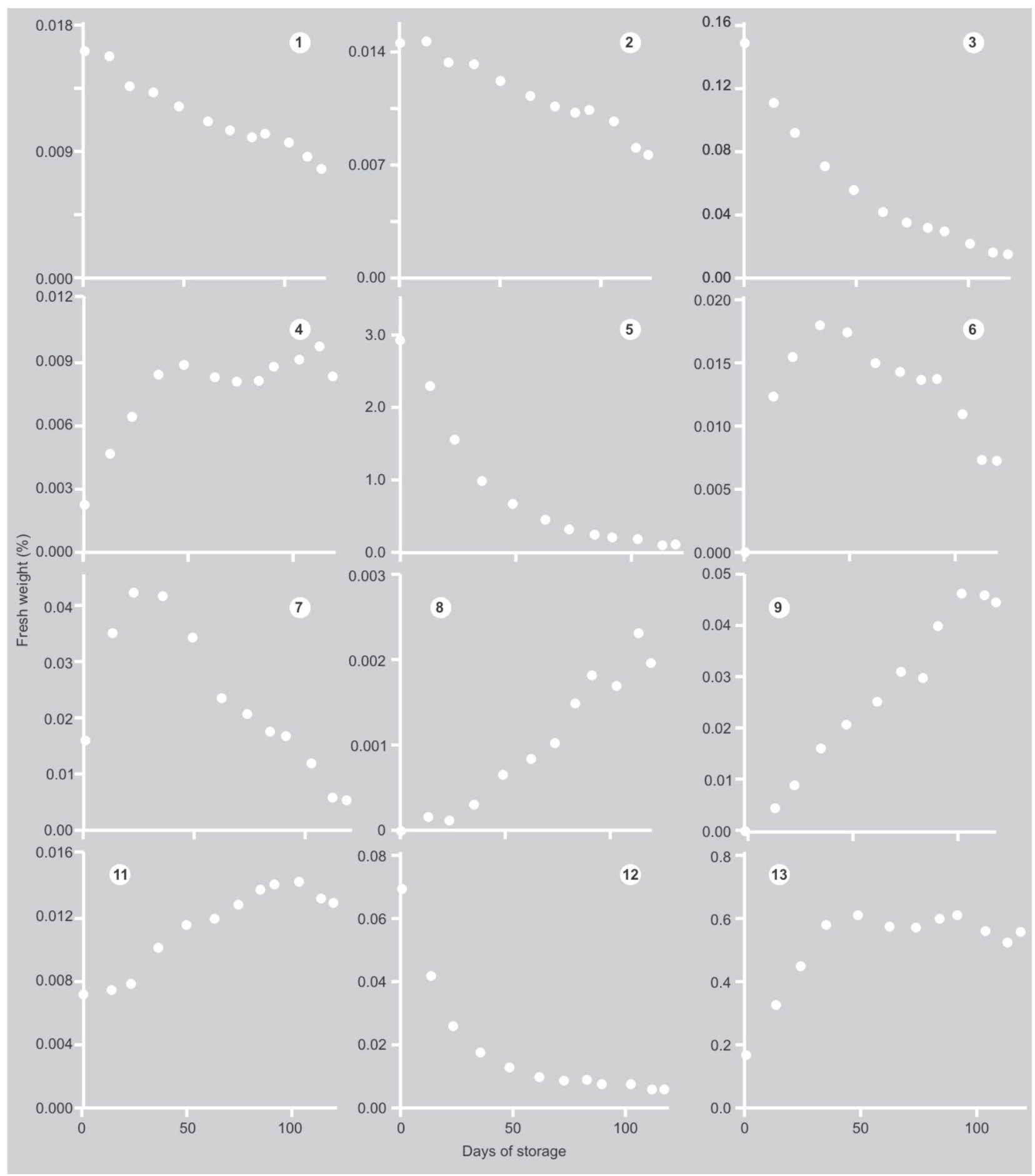

\section{Figure 7.}

Evolution of the compounds detected in the HPLC chromatograms of the extraction media from vanilla pod slices treated at $55^{\circ} \mathrm{C}$. Identities of peaks as follows: 1: unknown glucoside, 2: vanillic acid glucoside, 3: $p$-OHbenzaldehyde glucoside, 4: unknown aglycon, 5: glucovanillin, 6: unknown aglycon, 7: unknown aglycon, 8: unknown aglycon, 9: vanillic acid, 11: $p$-OHbenzaldehyde, 12: unknown glucoside, 13: vanillin. 
initial glucovanillin content, directly linked to the temperatures involved and the lengths of time when the pods are exposed to heat, and this at constant water content. Since during the first two critical steps of the traditional process ("killing" and sweating), the pod dry matter content changes little [8], the above proposals remain valid in the frame of the vanilla curing.

Thus, optimization of a curing pattern would be a compromise between the speed and extent of heat denaturation and the optimization of the working conditions under which the residual $\beta$-glucosidase will work afterwards: for example, a long "killing" treatment at a moderate temperature (e.g., $50^{\circ} \mathrm{C}$, if high enough to arrest the vegetative life of the pod and to disrupt the vacuolar membrane) will allow a maximum rate of hydrolysis of $\beta$-glucosides, while enzyme activity will be lost progressively to an unknown residual amount. Márquez and Waliszewski suggested, from their in vitro study of thermal inactivation of vanilla $\beta$-glucosidase, such a "cold killing" [17]. The sweating step is also important since pods are wrapped in woolen cloth, placed in closed boxes lined with the same cloth, and stored for a while [15], conditions under which the residual heat from the "killing" step is kept, i.e., the temperature remains sufficiently high for a day $[8,15]$ at a level where the residual $\beta$-glucosidase works rapidly before progressively falling by heat denaturation; this step was likely empirically promoted for this reason.

On top of that, the purified vanilla $\beta$-glucosidase is very unstable under pH 5.6 (complete loss of activity in $4 \mathrm{~h}$ at $20^{\circ} \mathrm{C}$ ) [5]. Since the vacuole occupies $\sim 93 \%$ of the intracellular volume [4], and because upon senescence or curing the tonoplast seems to be disrupted [11], it is reasonable to think that, under these conditions, the vacuolar juice and the cytoplasm ( $\mathrm{pH} \sim 7.2-7.4,[23])$ are mixed, and that the $\mathrm{pH}$ measured on a crushed vanilla pod ( $\mathrm{pH} \sim 5.2)$ is the vacuolar one. Thus, in addition to the heat denaturation occurring during the curing process, the $\beta$-glucosidase is also affected by the acidic $\mathrm{pH}$ generated by the decompartmentation [11] and blending of cell contents [24].
In the end, infinitesimal amounts of $\beta$-glucosidase are available for glucovanillin hydrolysis, which partly explains the length of the curing process; it is therefore not surprising that authors have not been able to measure this activity in heat-treated pods [9, 25]. However, this impossibility is not contradictory with the fact that all phenolic aglycons initially present as $\beta$-glucosides are produced by enzymatic hydrolysis. Kanisawa reported two $\beta$-glucosidases in vanilla [19], and this proposal was taken by Dignum et al., who proposed that the glucosidase "specific" to glucovanillin would resist the heat denaturation while the "non-specific" one, also active on $p$-nitrophenyl $\beta$-glucoside, would be denatured [9]. We have doubts about the putative existence of this second enzyme since Kanisawa never published a complete purification procedure or an extensive characterization (substrate specificity and kinetics) of this so-called "specific" enzyme; furthermore, we measured for several years the $\beta$-glucosidase activities on pNPG and glucovanillin and systematically found that their ratio was constant in all instances (diverse purification steps, direct measurements on vanilla pods, etc.).

Kinetics of the pure vanilla $\beta$-glucosidase in dilute media shows a typical Michaelis mode of functioning with the reaction rate being first-order for low glucovanillin concentrations $\left(<<K_{\mathrm{m}}\right)$ and zero-order, i.e., $V_{\text {max }}$, for high levels ( $\left.>K_{\mathrm{m}}\right)$ ([5], this work); the enzyme, a tetramer [5], does not show an allosteric behavior under these dilute conditions (see below). We have no explanation for the reason why formerly published $K_{\mathrm{m}}$ for $p$-nitrophenyl $\beta$-glucoside and glucovanillin [5] differ from those given in this work which, in the end, are closer, and even identical for glucovanillin, to those published by Dignum et al. [10]. This constant was not affected when $\mathrm{pH}$ was changed to 5.2 with the presence of $150 \mathrm{mM}$ glucose.

Kinetics of the $\beta$-glucosidase in vivo, i.e., in the heat-treated tissues, shows, against glucovanillin, an apparent allosteric behavior, compatible with the enzyme being a tetramer. Fitting the experimental curve $[v=\mathrm{f}(\mathrm{s})]$ with a Hill equation yielded the best fit with a Hill coefficient of 2.9, indicating a possible positive cooperativity between the monomers in the ligand binding. The 
$K_{0.5}$ for glucovanillin was found at $21.8 \mathrm{mM}$, i.e., four times higher than the $K_{\mathrm{m}}$ of the pure $\beta$-glucosidase in a dilute medium: the $\beta$-glucosidase thus exhibits in vivo a lower affinity for its substrate than in dilute conditions; however, one should bear in mind that concentrations of solutes, including proteins, in the aqueous phase of the heattreated tissues might change the affinity constant and they remain unknown at the moment.

Linear modes of hydrolysis of unknown glucoside $\left(n^{\circ} 1\right)$ and vanillic acid glucoside also suggest that the $\beta$-glucosidase does not work in vivo under a Michaelian mode, since due to their very low concentrations, the reaction rate must vary linearly (firstorder with concentration) while it was constant; vanillic acid glucoside was hydrolyzed much more slowly than glucovanillin, as reported by Dignum et al. [9, 10]

Thus, this apparent change in its mode of functioning, from Michaelian to allosteric, if actual, requires extensive research, taking into account the physico-chemical status of the symplasmic medium after heat treatment.

\section{Conclusion}

Very slow kinetics of hydrolysis of phenolic $\beta$-glucosides in heat-treated vanilla pods results, after heat denaturation, from the action of residual trace amounts of $\beta$-glucosidase. We showed that this $\beta$-glucosidase, a tetramer, does not behave in heattreated vanilla tissues as a Michaelian enzyme, but might work under an allosteric mode with a reduced affinity for its natural substrate, glucovanillin.

\section{Acknowledgements}

Thanks are due to Dr. M. Grisoni (CIRAD, Réunion Island) for the gift of vanilla pods.

\section{References}

[1] Cameron K.M., Recent advances in the systematic biology of vanilla and related orchids
(Orchidaceae: subfamily Vanilloideae), in: Proc. Vanilla, First Int. Cong., Princeton, USA, Carol Stream, Allured Publ. Corp., USA, 2005, pp. 89-93.

[2] Havkin-Frenkel D., French J.C., Pak F., Frenkel C., Inside vanilla: Vanilla planifolia's botany, curing options and future market prospects, Perfum. Flavour. 30 (2005) 36-55.

[3] Odoux E., Brillouet J.-M., Anatomy, histochemistry and biochemistry of glucovanillin, oleoresin and mucilage accumulation sites in green mature vanilla pod (Vanilla planifolia; Orchidaceae): a comprehensive and critical reexamination, Fruits 64 (2009) 221-241.

[4] Odoux E., Escoute J., Verdeil J.-L., Brillouet J.-M., Localization of $\beta$-glucosidase activity and glucovanillin in vanilla bean (Vanilla planifolia Andrews), Ann. Bot. 92 (2003) 437-444.

[5] Odoux E., Chauwin A., Brillouet J.-M., Purification and characterization of vanilla bean (Vanilla planifolia Andrews) $\beta$-D-glucosidase, J. Agric. Food Chem. 51 (2003) 3168-3173.

[6] Kanisawa T., Flavor development in vanilla beans, Kouryou 180 (1993) 113-123.

[7] Arana F.E., Action of a $\beta$-glucosidase in the curing of vanilla, Food Res. 288 (1943) 343351.

[8] Odoux E., Changes in vanillin and glucovanillin concentrations during the various stages of the process traditionally used for curing Vanilla fragrans in Réunion, Fruits 55 (2000) 119-125.

[9] Dignum M.J.W., Kerler J., Verpoorte R., Vanilla curing under laboratory conditions, Food Chem. 79 (2002) 165-171.

[10] Dignum M.J.W., van der Heijden R., Kerler J., Winkel C., Verpoorte R., Identification of glucosides in green beans of Vanilla planifolia Andrews and kinetics of vanilla $\beta$-glucosidase, Food Chem. 85 (2004) 199-205.

[11] Odoux E., Escoute J., Verdeil J.-L., The relation between glucovanillin, $\beta$-glucosidase activity and cellular compartmentation during the senescence, freezing and traditional curing of vanilla beans, Ann. Appl. Biol. 149 (2006) 43-52.

[12] Márquez O., Waliszewski K.N., The effect of thermal treatment on $\beta$-glucosidase inactivation in vanilla bean (Vanilla planifolia Andrews), Int. J. Food Sci. Technol. 43 (2008) 1993-1999.

[13] Roux P., Études morphologiques et anatomiques dans le genre Vanilla, in: Bouriquet G. (Ed.), Le vanillier et la vanille dans le monde, Lechevalier, Paris, France, 1954, pp. 44-92. 
[14] French J.C., Development of vanilla-bearing placental trichomes, in: Proc. Vanilla, First Int. Cong., Princeton, USA, Carol Stream, Allured Publ. Corp., USA, 2005, pp. 71-77.

[15] Krishnakumar V., Bindumol G.P., Potty S.N., Govindaraju C., Processing of vanilla (Vanilla planifolia Andrews) beans - Influence of storing fresh beans, killing temperature and duration of killing on quality parameters, $\mathrm{J}$. Spices Aromat. Crops 16 (2007) 31-37.

[16] Hanum T., Changes in vanillin and activity of $\beta$-glucosidase and oxidases during post harvest processing of vanilla beans (Vanilla planifolia), Bull. Teknol. Ind. Pagan 8 (1997) 46-52.

[17] Márquez O., Waliszewski K.N., Oliart R.M., Pardio V.T. Purification and characterization of cell-wall bound peroxidase from vanilla bean, Lebens. Wiss. u-Technol. 41 (2008) 1372-1379.

[18] Waliszewski K., Márquez O., Pardio V.T., Quantification and characterization of polyphenol oxidase from vanilla bean, Food Chem. 117 (2009) 196-203.

[19] Kanisawa T., Tokoro K., Kawahara S., Flavour development in the beans of Vanilla planifolia, in: Kurihara K., Suzuki N., Ogawa H. (Eds.), Olfaction taste XI, Proc. Int. Symp., Springer, Tokyo, Japan, 1994, pp. 268-270.

[20] Perez Silva A., Contribution à l'étude de la genèse des composés d'arôme au cours du procédé mexicain de transformation de la vanille (Vanilla planifolia Jackson), PhD Thesis, Univ. Montpellier II, France, 2006.

[21] Yonetani T., Park S., Tsuneshige A., Imai K., Kanaori K., Global allostery model of hemoglobin - Modulation of $\mathrm{O}_{2}$ affinity, cooperativity, and Bohr effect by heterotropic allosteric effectors, J. Biol. Chem. 277 (2002) 34508-34520.

[22] Perez-Silva A., Odoux E., Brat P., Ribeyre F., Rodriguez-Jimenes G., Robles-Olvera V., Garcia-Alvarado M.A., Günata Z., GC-MS and GC-olfactometry analysis of aroma compounds in a representative organic aroma extract from cured vanilla (Vanilla planifolia G. Jackson) beans, Food Chem. 99 (2006) 728-735.

[23] Roberts J.K.M., Ray P.M., Wade-Jardetzky N., Jardetzky O., Estimation of cytoplasmic and vacuolar $\mathrm{pH}$ in higher plants by ${ }^{31} \mathrm{P}$ NMR, Nat. 283 (1980) 870-872.

[24] Mariezcurrena M.D., Zavaleta H.A., Waliszewski K.N., Sanchez V., The effect of killing conditions on the structural changes in vanilla (Vanilla planifolia Andrews) pods during the curing process, Int. J. Food Sci. Technol. 43 (2008) 1452-1457.

[25] Ranadive A.S., Szkutnica K., Guerrera J.G., Frenkel C., Vanillin biosynthesis in vanilla beans, in: Proc. IX Int. Cong. Ess. Oils, Singapore, 1983, pp. 147-154.

\section{Cinética del funcionamiento in vivo de una $\beta$-glucosidasa hacia la liberación de la glucovainillina, y de glucósidos fenólicos conexos en la vaina de la vainilla sometida a un tratamiento térmico (Vanilla planifolia, Orchidaceae).}

Resumen - Introducción. El procedimiento tradicional de preparación de las vainas de vainilla engloba una etapa de escaldado y otra de secado, durante las cuales las vainas se someten al calor $\left(35-65^{\circ} \mathrm{C}\right)$ de duración variable. Por mucho que se sepa que la liberación de la vainillina y de otras composiciones fenólicas a partir de sus respectivos glucósidos no aromáticos se debe a la acción de una $\beta$-glucosidasa endógena, se desconocen aún sus parámetros cinéticos de funcionamiento in vivo. Material y métodos. Primero se trataron unas vainas verdes maduras durante $2 \mathrm{~h}, 50{ }^{\circ} \mathrm{C}, 55^{\circ} \mathrm{C}$ y $60{ }^{\circ} \mathrm{C}$, respectivamente, y luego se almacenaron durante 118 días a $27^{\circ} \mathrm{C}$. Se extrajeron los glucósidos de fenoles así como sus respectivos aglicones en intervalos regulares durante el periodo de almacenamiento y se analizaron mediante HPLC. Resultados y discusión. Se hidrolizaron lentamente todos los glucósidos de fenoles durante el periodo de almacenamiento con liberación de vainillina, $p$-hidroxibenzaldehído, ácido vainíllico y otros aglicones desconocidos. Lo esencial de la actividad $\beta$-glucosidasa se desnaturalizó debido al calor durante el tratamiento preliminar. El análisis de sus parámetros cinéticos mostró que la encima adopta in vivo un modo de funcionamiento alostérico con una afinidad por la glucovainillina más débil que in vitro, en donde se comporta como una enzima michaeliana. Conclusión. La confirmación del mecanismo alostérico de la $\beta$-glucosidasa in vivo de la vainilla requiere un estudio profundizado.

Francia / Vanilla planifolia / vainilla / procesamiento / calor / glucovanillina / $\beta$-glucosidasa / constante de afinidad / alosterismo 